doi: $10.35757 /$ KiS.2019.63.2.11

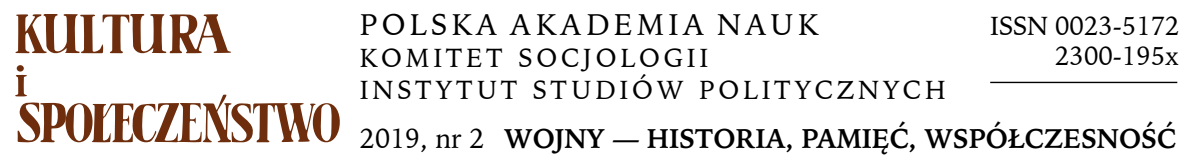

WALDEMAR RAPIOR

Poznań

\title{
CZY JESTEŚMY ODPOWIEDZIALNI ZA WSPÓLNY ŚWIAT? WOJNA W SYRII I DYLEMATY WSPÓŁCZESNEGO ZACHODU
}

\section{TEREN BADAŃ I METODA}

„Demokratyczna interwencja pokojowa”, „nigdy więcej!”, „musimy coś zrobić”, „międzynarodowa solidarność”, „zasada odpowiedzialności za ochronę" (responsibility to protect - R2P) ${ }^{1}$ - te hasła co najmniej od roku 1945 stały się odzwierciedleniem podstawowych wartości, którymi miał się kierować świat zachodni $\mathrm{w}$ działaniach na arenie międzynarodowej (zob. Judt 2015). Susie Linfield [NYRDaily 09.02.2019], odwołując się do nich, ocenia, że wojna w Syrii jest „największą polityczną porażką ostatniej dekady - historycy mogą z łatwością uznać ją za powód do wstydu naszej generacji”. Podobne zastrzeżenia sformułował Michael Ignatieff [NYRB

Adres do korespondencji: waldekrapior@gmail.com; ORCID 0000-0002-3664-7821

${ }^{1}$ Doktryna podpisana przez wszystkie państwa członkowskie ONZ w 2005 roku w Nowym Jorku podczas światowego szczytu tej organizacji. Daje ona mandat humanitarnym interwencjom, gdy tyran, jak Baszar al-Asad, rozpocznie wojnę z własnymi obywatelami, co doprowadzi do ludobójstwa, zbrodni wojennych, zbrodni przeciwko ludzkości, czystek etnicznych. Jej powstanie, pisała Dorota Heidrich (2013, s. 190), wiąże się z pragnieniem znalezienia odpowiedzi na pytanie: ,jeśli interwencja humanitarna jest postrzegana jako bezprawny zamach na suwerenność państwową, to jak wspólnota międzynarodowa powinna reagować na masowe naruszenia praw człowieka czy zbrodnie, które uderzają w podstawowe wartości moralne całej ludzkości, tak jak to miało miejsce w Rwandzie czy Srebrenicy?”. 
17.02.2015], pisząc: „następne generacje zapytają, dlaczego europejscy przywódcy na to pozwolili?”, z kolei George Soros [NYRB 10.11.2016] wzywał: „nie stójcie bezczynnie”, „rozpowszechniajcie głos waszego oburzenia”, opinia publiczna wymusi „na prezydencie Putinie zakończenie jego ohydnej zbrodni przeciwko ludzkości". Wypowiedzi te sugerują, że istnieje wspólnota moralna, która definiuje powinność etyczną nas, ludzi Zachodu. Brzmi ona: gdy widzimy cierpienie, powinniśmy coś zrobić (Sontag 2010). Instancją, która osądzi brak działania Zachodu w Syrii, w obliczu bierności polityków oraz braku presji ze strony opinii publicznej, będą - jak wskazywali Linfield, Ignatieff i Soros - przyszłe pokolenia. „Dlaczego - pytał Hugh Eakin w 2013 roku - dostrzegając wyraźnie widoczną potrzebę pilnej pomocy tym [uchodźcom z Syrii], którzy teraz przybywają [do UE], europejscy przywódcy są tak ambiwalentni w pomaganiu im?" [NYRB 10.10.2013]

Wszystkie cztery głosy — Linfield, Ignatieffa, Sorosa i Eakina - pojawiły się na łamach dwutygodnika „New York Review of Books” (NYRB) i wskazują na załamanie się wspólnoty moralnej świata zachodniego. Wojna w Syrii pokazała, że powoływanie się na solidarność z ofiarami wojen nie wystarczy, aby zmotywować decydentów i opinię publiczną do działania na rzecz pokoju. Autorki i autorzy artykułów NYRB zdają sobie $z$ tego sprawę. O czym piszą w swych artykułach w związku w wojną w Syrii? Postaram się tu przedstawić, czym zostały zastąpione wezwanie „musimy coś zrobić” oraz „widzieć-działać” jako wzór reakcji na cudze cierpienie.

Przedmiotem analizy były teksty bezpośrednio dotyczące konfliktu w Syrii, wyodrębnione spośród materiałów opublikowanych w NYRB od 11 marca 2011 r. (data antyreżimowego powstania w Syrii) do czasu analizy (marzec 2019) ${ }^{2}$. Terenem moich badań stał się korpus tekstów w sumie 36 artykułów ${ }^{3}$. Przystąpiłem do analizy z pytaniami: Jaki obraz wojny w Syrii przedstawiają ich autorzy? Jaki przekaz o tej wojnie otrzymuje czytelnik, który prenumeruje NYRB i regularnie czyta publikowane $\mathrm{w}$ nim artykuły?

Za wyborem NYRB przemawia fakt, że publikują w tym piśmie intelektualiści, badacze, dziennikarze, ci, „którzy się liczą” — jak pisał Tony Judt (2011, s. 458) — mają grono czytelników, a ich idee są często ko-

\footnotetext{
${ }^{2}$ Na łamach NYRB ukazywały się w tym czasie również teksty dotyczące ISIS, Iraku, Jemenu, prawa humanitarnego itd., które pośrednio nawiązywały do wojny w Syrii. Zapoznałem się z nimi także, choć nie były przedmiotem analizy.

${ }^{3}$ Dane tych artykułów (oraz kilku innych tekstów z NYRB, powiązanych z podjętym tematem) znajdują się na końcu bibliografii.
} 
mentowane ${ }^{4}$. Judt twierdził, że nie istnieje „globalna” publiczność. Jeśli publikujesz esej w NYRB, to być może przeczytają cię na całym świecie, ale „twoją prawdziwą publicznością jest społeczność czytelników uczestniczących $w$ danej debacie. To w jej ramach pisarz może wywierać wpływ i trwale coś znaczyć" (Judt 2015, s 458).

Analizę przeprowadziłem w marcu 2019 roku. Nie jest to typowa analiza treści ${ }^{5}$. Głównym zadaniem, jakie sobie wyznaczyłem, było zrozumienie założeń, które stały u podstaw argumentów wygłaszanych na łamach NYRB i konstruowały przestrzeń tego, co możliwe/niemożliwe do zrealizowania w Syrii, Stanach Zjednoczonych i krajach UE. Kierowałem się paradygmatem wywiadu rozumiejącego Jean-Claude'a Kaufmanna (2010). Każdy artykuł przeczytałem (czasem kilkukrotnie) jeden po drugim, poczynając od najstarszego [09.06.2011] do najnowszego [07.02.2019]. Tworzyłem fiszki i robiłem notatki, w których zapisywałem argumenty, sądy, polemiki, stwierdzenia pojawiające się w artykułach. W ten sposób zidentyfikowałem to, co było ważne z perspektywy autorek i autorów.

W toku analizy odniosłem wrażenie, że piszący często próbują w swych tekstach rozwikłać jakiś konkretny problem albo opowiadają się po jakiejś stronie dylematu. Określenia „dylemat” na łamach NYRB [07.11.2013] użył Mark Danner, recenzując książkę The Syria Dilemma (Hashemi, Postel 2013). Wskazuje ono na potrzebę dokonania wyboru między dwiema równoprawnymi możliwościami ${ }^{6} \mathrm{i}$ choć nie pojawiło się $\mathrm{w}$ innych artykułach, uznałem, że jest dobrym narzędziem porządkowania ich treści. Piszący w NYRB nie zawsze się ze sobą zgadzają. Kenneth Roth, szef Human Rights Watch, regularnie publikujący w tym periodyku, przekładał humanitarny plan nad militarną interwencję. Michael Ignatieff natomiast, także stały eseista NYRB, domagał się od przywódców Zachodu interwencji wojskowej w Syrii. Hugh Eakin pytał, jak zareagować na kryzys uchodźczy z 2015 roku, gdy w Europie wzrasta znaczenie ruchów nacjonalistycznych: czy możemy pomóc „obcym”, a jednocześnie zapewnić poczucie bezpieczeństwa „naszym”? Molly Crabapple [06.12.2018] pisała natomiast:

\footnotetext{
${ }^{4}$ NYRB jest czasopismem o sporym zasięgu i odziaływaniu na debatę publiczną, zwłaszcza w Stanach Zjednoczonych i w krajach UE (nakład papierowy to 132 tys. - stan na 2017 rok; dostępna jest też wersja on-line i MOBI).

${ }^{5}$ Słów kluczowych, ich liczby w tekstach oraz położenia w obrębie całości tekstu, a także w poszczególnych akapitach czy nawet w całym korpusie tekstów, o wiele lepiej poszukują dziś maszyny niż ludzie.

${ }^{6}$ We wprowadzeniu do tej książki Nader Hashemi i Danny Postel piszą, że poglądy autorytetów zdecydowanie różnią się w kwestii tego, jakie działania należy podjąć w Syrii.
} 
„Emigranci są demonizowani. Aktywiści aresztowani. Demagodzy obiecują mury. W czasach takich jak te, gdy szowiniści starają się odmalować uchodźców jako plagę i terrorystów, opowieści są jedyną możliwością, aby z nimi walczyć". Dwa tygodnie później Ed Vulliamy [20.12.2018] podważał skuteczność oddziaływania opowieści, zdjęć i obrazów na decydentów w Europie i Stanach Zjednoczonych.

Porównując argumenty pojawiające się w poszczególnych tekstach, zacząłem szukać dylematów wojny w Syrii oraz dylematów związanych z konsekwencjami tej wojny. Takie postępowanie jest zgodne ze wskazówką Kaufmanna (2010, s. 33-34): „Teren badań nie jest już instancją weryfikacyjną wcześniej ustalonej problematyki, lecz jej punktem wyjścia" Zamiast rekonstruować treść artykułów, starałem się zrozumieć dylematy, które dostrzegłem podczas czytania i porównywania tekstów z NYRB. Odzwierciedlają one złożoność sytuacji w Syrii oraz zmiany światowych jej uwarunkowań. Stały czytelnik NYRB nie otrzymuje jednego głosu („głosu NYRB”) czy spójnych wiadomości o Syrii, lecz niejako „żywą” relację ${ }^{7}$. Aby ułatwić zrozumienie istoty wyodrębnionych przeze mnie w tej narracji dylematów, scharakteryzuję pokrótce sytuację w Syrii, a przede wszystkim podmioty uwikłane $\mathrm{w}$ ten konflikt.

\section{SYRIA (2011-2019)}

Syria jest krajem o złożonej strukturze etnicznej i religijnej. W 2011 ro$\mathrm{ku}-\mathrm{w}$ czasie wybuchu trwającego do dziś konfliktu - 74\% populacji stanowili sunnici, mieli jednak już niewielki wpływ na politykę rządu. Po uzyskaniu niepodległości w 1946 roku dominującą cechą zmieniających się władz tego postkolonialnego obszaru były niezdolność do rozwiązania problemów politycznych, ekonomicznych, wyznaniowych oraz wynikające $z$ tego liczne konflikty i seria zamachów stanu, które wielokrotnie radykalnie zmieniały politykę wewnętrzną i zagraniczną choć generalnie przewagę mieli wówczas sunnici (zob. Jomma 2018). Lata niestabilnych rządów doprowadziły do zamachu stanu dokonanego 8 marca 1963 r. przez grupę oficerów związanych z partią Al-Baas (alawici, odłam islamu szyickiego),

\footnotetext{
${ }^{7}$ Niestabilność sytuacji w Syrii podkreśla fakt, że choć większość z analizowanych artykułów jest datowana, co sugeruje, iż odnoszą się do stanu wojny w danym dniu, to istnieje miesięczne opóźnienie między datą ich napisania a datą publikacji — w trakcie tego miesiąca wiele mogło się wydarzyć. Na przykład artykuł Annie Sparrow Syria’s Polio Epidemic, datowany na 20 stycznia 2014 r., ukazał się w numerze NYRB z 20 lutego 2014 r.; tekst Charlesa Glassa Syria: On the Way to Genocide? z 7 listopada został wydrukowany w numerze z 5 grudnia $2013 \mathrm{r}$.
} 
która zaczęła konsolidować władzę, walcząc o „wolność i jedność arabską”. Był to początek wieloletnich nieprzerwanych rządów tej partii. 22 lutego 1971 r. wskazała ona jedynego kandydata na urząd prezydenta. Był nim Hafiz al-Asad - o jego wyborze obywatele zdecydowali w referendum, ale odtąd „władza siłą wymuszała posłuszeństwo społeczeństwa, ograniczając reformy społeczne i ekonomiczne" (Jomma 2018, s. 10). Po śmierci Hafiza al-Asada w 2000 roku władzę przejął jego syn - Baszar al-Asad, który kontynuował politykę ojca. W 2011 roku popierający rząd alawici stanowili w społeczeństwie mniejszość $\left(12 \%^{8}\right)$, podobnie jak chrześcijanie (10-12\%), którzy w al-Asadzie dostrzegali gwaranta „kruchego ładu i względnego spokoju" (Jomma 2018, s. 519) ${ }^{9}$.

Wewnętrzne problemy w totalitarnym państwie pozostawały nierozwiązane. Sytuację komplikował fakt, że w latach 1995-2011 Syria przeżywała boom demograficzny. Urodziło się wówczas $9 \mathrm{mln}$ dzieci, co stanowiło $65 \%$ populacji 22,5 -milionowego państwa ${ }^{10}$. Syryjskie społeczeństwo jest demograficznie młode, co wpłynęło na przebieg konfliktu i oblicze wojny. W 2013 roku cztery osoby na dziesięć miały około 15 lat.

Niebagatelnym czynnikiem destabilizacji była susza, która w latach 2006-2010 nawiedziła tereny wschodniej Syrii — opanowane później przez Państwo Islamskie. Półtora miliona rolników i hodowców bydła straciło cały majątek. „Ci ludzie — opowiadał Wojciech Wilk (2019), prezes Polskiego Centrum Pomocy Międzynarodowej — przenieśli się do dzielnic biedy w kilku miastach w zachodniej Syrii, jak Dara, Douma czy Homs". To tam rozpoczęły się protesty przeciwko rządom al-Asada. Michel Kilo - syryjski pisarz, obrońca praw człowieka — na łamach gazety „Al-Rai al-Aam” tak oceniał sytuację w Darze: „To nadgraniczne miasto jest w roz-

8 Trzeba zaznaczyć, że przekonanie, iż większość alawitów wzbogaciła się za rządów al-Asada, nie jest prawdziwe (Glass [NYRB 06.11.2014]).

9 Ponadto Syrię zamieszkiwali wówczas: szyici (1\%); druzowie (3\%); a także pół miliona Palestyńczyków; 120000 Libańczyków, którzy uciekli do Syrii w 2006 roku przed wojną Izraela $z$ Hezbollahem, 2,5 mln Kurdów oraz wiele innych mniejszości (Romowie, Turkmenii, Grecy, Czerkiesi, Albańczycy, Ormianie).

10 Wiele $z$ nich wkrótce miało przestać chodzić do szkoły. W wyniku konfliktu pięć milionów dzieci musiało opuścić dom, z czego milion walczyło na froncie, a milion to uchodźcy (Sparrow [20.02.2014; 07.05.2015]). W 2014 roku zabito w działaniach zbrojnych 11500 dzieci, połowę z nich w bombardowaniu szkół, szpitali, domów, 1500 zostało straconych, zastrzelonych przez snajperów lub torturowanych na śmierć. W sierpniu 2013 roku 128 zginęło w ataku chemicznym. Miliony niedożywionych dzieci przeżywają traumę, cierpią z powodu zapalenia wątroby i tyfusu, 100000 dzieci jest naznaczonych leiszmaniozą, chorobą pasożytniczą, która gwałtownie rozprzestrzeniła się podczas wojny, powróciło też polio, odra, różyczka. 
paczliwej sytuacji, i to już od dawna. Nie ma żadnych możliwości rozwoju, chłopi żyją w biedzie. Ich pola wysychają. Wydarzenia w Tunezji i Egipcie dodały tym ludziom odwagi, by wreszcie zacząć się bronić" (cyt. za Jomma 2018, s. 484).

Arabska Wiosna, wbrew przewidywaniom al-Asada, który wierzył w swój aparat represji, dała młodym Syryjczykom dodatkowy impuls do protestów. W pokojowych demonstracjach domagali się oni na początku nie tyle ustąpienia prezydenta, ile poprawy perspektyw na rynku pracy i możliwości awansu społecznego. Pod koniec lutego 2011 roku, grupa dziewiętnaściorga dzieci w wieku od 9 do 15 lat na murach szkoły w Darze wykonała graffiti o treści: „Kolej na ciebie, doktorze” ${ }^{11}$. Była to reakcja na aresztowanie i upokorzenie (przez zgolenie włosów) lekarki Aiszy al-Masalmy, która w rozmowie $z$ koleżanką wyraziła zadowolenie $z$ upadku prezydenta Egiptu i liczyła na szybki schyłek rządów al-Asada. Uczniowie zostali aresztowani, część $z$ nich torturowano, a rodzicom powiedziano, że mają o swoich dzieciach zapomnieć i spłodzić nowe (Jomma 2018, s. 483). Ludzie wyszli na ulicę. Protesty pod hasłem „Lud syryjski nie da się upokorzyć" zostały stłumione siłą (ocenia się, że zginęło 49-270 osób). Mieszkańcy innych miast okazali solidarność ze społecznością Dary — rewolucja objęła cały kraj. Wybuchła wojna domowa.

Postaram się skrótowo scharakteryzować główne strony konfliktu, zarówno w obrębie społeczności syryjskiej, jak i w gronie podmiotów interweniujących. Zarysuję też zasadnicze motywy ich działań.

Wewnętrzne strony konfliktu syryjskiego

1. Dyktator al-Asad i siły rządowe pragnące obronić swoją pozycję (głównie alawici, którzy współpracowali z szyitami).

2. Wolna Armia Syrii — „demokraci”, w przeważającej większości młodzi mężczyźni popierający Arabską Wiosnę (głównie sunnici). W dużej mierze wojskowi zbiegli z armii rządowej i przeciw niej występujący zbrojnie. Nie była to spójna grupa, o wspólnym przywódcy. W początkowych latach wojny Wolna Armia Syrii miała wsparcie prezydenta Turcji Erdoğana (sunnita) i prezydenta Stanów Zjednoczonych.

3. Kurdowie - po 1946 roku odrzucili przynależność do narodu syryjskiego, za co zostali w części pozbawieni obywatelstwa Syrii, a w 1962 roku uznano ich za ludność cudzoziemską (7 kwietnia 2011 r. w obawie

${ }^{11}$ Al-Asad legitymuje się dyplomem uzyskanym na wydziale medycyny Uniwersytetu Damasceńskiego. 
przed buntem al-Asad przywrócił im obywatelstwo). Kurdowie skrupulatnie budowali autonomię: ożywili własny język, stworzyli własny system edukacji i media oraz oddziały wojskowe. $\mathrm{Na}$ arenie międzynarodowej autonomia ta została zaznaczona podczas rokowań w Genewie w 2014 roku, gdy reprezentacja Kurdów odmówiła dołączenia do „demokratów” i opozycji rządu al-Asada. W wyniku wojny powstały nowe rozwiązania prawne, które po raz pierwszy brały pod uwagę interesy mniejszości. Zaliczał się do nich przedstawiony w 2014 roku projekt konstytucji kantonu Rożawa (północna część Syrii w dużej mierze kontrolowana przez Kurdów; Jomma 2018, s. 106). Ponadto dwieście tysięcy syryjskich Kurdów przeniosło się do Iraku, gdzie walczyli z Państwem Islamskim.

4. Państwo Islamskie (ISIS) - głównie fundamentaliści sunniccy stroną w konflikcie stało się w 2014 roku. Stanowili wyzwanie zarówno dla al-Asada i jego sojuszników, jak i dla Zachodu, który uznał ISIS za organizację terrorystyczną.

\section{Państwa interweniujące w konflikt syryjski}

1. Stany Zjednoczone ${ }^{12}$, a także Francja i Wielka Brytania wystąpiły przeciw al-Asadowi, ale od 2014-2015 wprost są już tylko przeciw ISIS. Interwencje świata zachodniego początkowo wiązały się ze wsparciem Kurdów i „demokratów” w walce z okrutną dyktaturą, ale w czasie wojny realistyczne cele przesunęły się od pośredniego obalenia dyktatora ich „rękami” do bezpośredniego pokonania fundamentalistów, którzy rozprzestrzenili się z Iraku.

2. Turcja wystąpiła przeciw Kurdom; początkowo także przeciw al-Asadowi, ale gdy popierająca go Rosja obiecała nie sprzyjać Kurdom, odstąpiła od zamiaru obalenia dyktatora. Prezydent Turcji widzi zagrożenie w autonomii Kurdów, którzy są największym narodem niemającym własnego państwa, a w Turcji żyje ich $12 \mathrm{mln}$. W tureckim interesie leży zatem zachowanie jedności terytorialnej Syrii.

3. Arabia Saudyjska (i jej sprzymierzeńcy w regionie Zatoki Perskiej) jako sunnickie państwo wyznaniowe jest przeciw Iranowi, który stanowi najsilniejszy szyicki kraj na współczesnym Bliskim Wschodzie. Interwencja Saudyjczyków osadzona jest w kontekście rywalizacji sunnicko-szyickiej. Zwycięstwo sunnitów skierowałoby Syrię ku Arabii Saudyjskiej i Turcji - krajom uważanym za głównych wrogów Iranu.

124 lutego 2012 r. prezydent Obama stwierdził, że al-Asad stracił jakąkolwiek legitymizację społeczną i tym samym nie powinien dalej sprawować władzy (zob. Jomma 2018, s. 500). 
4. Iran opowiada się za al-Asadem, dążąc do zachowania czy nawet rozszerzenia szyickiego wpływu w pasie od Iranu przez Irak do Syrii, Libanu i Morza Śródziemnego (tzw. szyicki półksiężyc). Współpracuje z szyickim Hezbollahem, dążącym do ustanowienia w Libanie republiki islamskiej na wzór Iranu, a przez Stany Zjednoczone uznawanym za organizację terrorystyczną. Szyicki półksiężyc jest nie do zaakceptowania przez sunnickie państwa arabskie, zwłaszcza Saudyjczyków. Ponadto Iran łączy z al-Asadem wrogość wobec Izraela i antyamerykańskie nastawienie.

5. Izrael jest przeciw Iranowi (oraz Hezbollahowi). Współpracuje z rządem Stanów Zjednoczonych, ale także z Rosją (w celu wywierania wpływu na Teheran). Izrael formalnie pozostaje w stanie wojny $z$ Syrią, okupując Wzgórza Golan. Osłabienie Syrii, a więc niekończąca się wojna domowa, leży w interesie tego kraju.

6. Rosja, podobnie jak niegdyś ZSRR, opowiada się za reżimem al-Asadów, aby powstrzymać wpływy Stanów Zjednoczonych w regionie. W toku wojny doszło do uzgodnienia interesów Rosji, Iranu i Turcji. Skutkiem tego jest utrzymanie się al-Asada. Ostatecznie Stany Zjednoczone uznały, że pokonały militarnie ISIS, a w końcu stwierdziły „milcząco”, że skoro al-Asad ma tak silnych mocodawców, to on pozostanie w roli zapory dla wpływu fundamentalizmu sunnickiego. Nie spełnią tej roli demokraci (los Wolnej Armii Syrii jest już przesądzony — nie liczy się ona w „nowej” Sryrii) ani Kurdowie (choć autonomia syryjska — Rożawa - może się jeszcze utrzymać, co będzie zależeć $z$ jednej strony od determinacji popierającego ją Zachodu, z drugiej — od siły dążenia al-Asada do jej likwidacji i poparcia Turcji w tym względzie) ${ }^{13}$.

Obok sił specjalnych interweniujących mocarstw w syryjskim konflikcie pewną rolę odrywały także organizacje humanitarne, jednak wobec ostrości konfliktu ich działania nie przynosiły zadowalających skutków. Kofi Annan, który z ramienia ONZ i Ligi Arabskiej przewodził pracami na rzecz pokoju w Syrii w latach 2011-2012, stwierdził, że jeszcze nigdy nie pracował tak ciężko $z$ tak marnym skutkiem. Jego plan pokojowy nie był respektowany przez siły rządowe. Ataki ze strony wojsk al-Asada, w których

13 Jonathan Steele [03.12.2015] rozpoczyna swój artykuł: „Każdy, kto szuka światełka w ciemności syryjskiej katastrofy, powinien udać się na północny-wschód kraju. Około 2,2 mln Kurdów stworzyło tam quasi-państwo, które jest zdumiewająco bezpieczne i dziwnie nieznane za granicą". Steele uważa, że cokolwiek się zdarzy, Arabowie nie odzyskają tych ziem. Kurdowie tam pozostaną. Czy jednak Damaszek zgodzi się na powstanie państwa federalnego? Z kolei Christian Caryl [08.12.2016] rozpatruje możliwość stworzenia państwa Kurdów. 
ginęli cywile, spowodowały, że rebelianci również przestali go respektować. Annan podał się do dymisji 2 sierpnia 2012 r.

Kreśląc obraz wojny w Syrii, trzeba pamiętać o cywilach, niebędących wszak jej stroną. Nie angażowali się oni bezpośrednio w walki, żyjąc bądź w strefach kontrolowanych przez rząd (cywile $z$ ubogich dzielnic zostali uznani przez al-Asada za wrogów), bądź w pozostających poza rządową kontrolą obszarach z brakiem dostępu do czystej wody, żywności, opieki lekarskiej, w ciągłym zagrożeniu przemocą. Tylko w rejonie Aleppo ponad milion osób było pozbawionych podstawowych elementów życia cywilnego. Jisr al-Shughour stało się miastem widmem — jego mieszkańcy uciekli przed represjami do pogranicznej miejscowości Hatay w Turcji. W 2013 roku cztery miliony Syryjczyków było „uchodźcami wewnętrznymi”; w 2015 już 7,6 mln. Za granicę uciekało kilka tysięcy osób dziennie. Na przykład w Egipcie w 2012 roku nie było żadnego syryjskiego uchodźcy, a rok później żyło ich tam sto tysięcy. W Libanie, kraju sunnickim (choć duże znaczenie ma tam Hezbollah, czyli szyici), znalazło się milion Syryjczyków — niedługo będą stanowić $25 \%$ jego populacji.

Skutki wojny w Syrii w krótkim czasie dały się odczuć także poza Bliskim Wschodem. 27 sierpnia 2013 r. austriacka policja znalazła opuszczone volvo - ciężarówkę-chłodnię wypełnioną ciałami siedemnastu uchodźców pozostawioną na jednej z autostrad. Wojna w Syrii przestała być odległa dla Europy. Frontex w raporcie rocznym przedstawił „milionowy biznes" szmuglerów, którzy pobierają opłatę w wysokości 4500-6000 euro za osobę za wejście na pokład łódki płynącej do UE. W zależności od statku (mogą one pomieścić od 200 do 800 osób) jedna podróż przynosi dochód w wysokości 2-4 mln euro. W 2015 r. do krajów UE przybyło ponad milion uchodźców z Syrii, wywołując kryzys uchodźczy, który polegał na otwartym braku solidarności między krajami UE w obliczu konieczności przyjęcia na własne terytorium ludzi szukających pomocy. Kryzys ten wzmocnił nastawienia nacjonalistyczne w takich krajach jak Włochy, Polska, Węgry.

Podobnie jak w przypadku braku współdziałania krajów UE w sprawie kryzysu uchodźczego, tak na szerszej arenie międzynarodowej można dostrzec brak współpracy między poszczególnymi państwami, które wspólnie mogłyby doprowadzić do przerwania konfliktu i rozwiązania go metodą pokojową. Wprawdzie można powiedzieć, że obecnie wojna syryjska zmierza ku końcowi, jednak dzieje się to wskutek splotu decyzji podejmowanych przez mocarstwa pojedynczo, w celu osłabienia własnego przeciwnika, a nie w wyniku międzynarodowej współpracy. Zaangażowane w konflikt strony występują „przeciw” komuś, a nie „za” — w imię obrony pokoju. 
Już w 2014 roku Glass [06.11.14] pisał, że w Damaszku sklepy są na nowo otwarte, kawiarnie serwują kawę. Ludzie nie chcą słyszeć o wojnie. Ignorują sporadyczne naloty. Udają, że nic się nie dzieje, dopóki dopóty bomba nie zabije kogoś z bliskich. Uczą się żyć z wojną w tle, są zmęczeni. W 2017 roku Lindsey Hilsum [23.11.2017] stwierdziła, że niebawem reżim zacznie pozorować, iż wojny nie było. Turyści znów będą przyjeżdżać do Palmiry. Otrzymają nową atrakcję: zaczną zgadywać, które elementy starożytnych budowli zostały zburzone w czasach Imperium Rzymskiego, a które wysadzili w powietrze fanatycy ISIS, którzy okupowali to miasto przez osiemnaście miesięcy w latach 2015-2017. W artykule z 8 marca 2018 r. Charles Glass przedstawił syryjską nową normalność: powojnie w Syrii to nie tyle brak wojny, ile brak pokoju, a rok później, 7 lutego 2019 r., pisał o „dzikim pokoju”. Powody wojny — korupcja, polityczne represje, zaniedbanie prowincji, ekonomiczna zapaść - nie są tematami w „nowej” Syrii. Wydaje się jednak — sugeruje ten uznany obserwator krajów Bilskiego Wschodu - iż „zwycięzcy” wiedzą, że jeśli nie wprowadzą zmian, prędzej czy później ktoś znów spróbuje obalić status quo.

\section{JAK DZIAŁAĆ? DYLEMATY ZWIĄZANE Z KRYZYSEM SYRYJSKIM}

Wyróżniłem pięć dylematów - wszystkie one dotyczyły pytania „jak działać?”. Każdy z nich opisałem i przedstawiłem tak, jak wyłonił mi się podczas analizy tekstów pochodzących z NYRB. Przedstawiam dylematy chronologicznie, od najstarszego do tego, którego zidentyfikowałem w najnowszych numerach korpusu analizowanych tekstów. Pierwszym z nich jest dylemat Obamy (dotyczy tego, jak powinniśmy działać „tam”, w miejscu katastrofy); drugi - dylemat Merkel (odnosi się do działania „tu”, w naszym kraju); trzeci — dylemat humanitaryzmu (jak połączyć działania „tu”, czyli mobilizowanie darczyńców, z działaniami „tam” — lokalnymi działaniami oddolnymi w kraju potrzebującym pomocy); czwarty — dylemat państw (jak połączyć „nas” i nasze interesy z „nimi” — dążeniami obywateli państw ogarniętych konfliktem); piąty — dylemat Colvin (jak relacjonować dla „nas”, mieszkańców Zachodu, wydarzenia „stamtąd”).

Zdaję sobie sprawę, że będzie to opis uproszczony, nie ma tu jednak miejsca na szczegółowe rozważania ${ }^{14}$. Moim zamiarem jest wskazanie

\footnotetext{
${ }^{14}$ Podejmując próbę teoretycznego uściślenia wyodrębnionych przeze mnie pięciu dylematów, ich krytyka oraz ustalenie, czy mają one moc objaśniania „ambiwalentnego zachowania” — jak pisze Eakin - przywódców i opinii publicznej Zachodu wobec wojny i uchodźców z Syrii, należałoby włączyć do korpusu analizowanych tekstów dodatkowy materiał empirycz-
} 
i nazwanie dostrzeżonych przeze mnie dylematów oraz pokazanie, że są one ze sobą związane - wszystkie odnoszą się do jednej i tej samej wojny - wojny w Syrii, ale stojące za nimi problemy wykraczają poza tę wojnę. Należy je rozważać wspólnie, nawet jeśli są odróżnialne analitycznie. Uważam, że odnoszą się one do najważniejszych, przynajmniej w najbliższej dekadzie, kwestii, z którymi świat demokratyczny będzie musiał się uporać, aby skutecznie zapewnić pokój na świecie.

\section{Dylemat Obamy: jak usunąć zło}

bez konieczności długotrwałego działania?

Na dylemat Obamy składają się „dylemat syryjski” — jak szybko i bez konieczności wikłania się w długotrwałą inwazję usunąć dyktatora (powszechnie uważano bowiem, że świat bez al-Asada, podobnie jak bez Saddama Husseina, będzie lepszy)?, oraz „dylemat retoryczny” — jak wycofać się z twarzą z własnych słów? Sedno dylematu Obamy stanowią nie uchodźcy, głód, brak wody, cierpienie cywilów, lecz arsenał chemiczny al-Asada i międzynarodowe normy prawne chroniące cywilów i żołnierzy przed użyciem niekonwencjonalnej broni.

W 2011 roku - przypominają artykuły w NYRB — prezydent Barack Obama oświadczył, że czas al-Asada już nadszedł. Być może sądził wówczas, że dyktator upadnie jak Ben Ali w Tunezji albo Hosni Mubarak w Egipcie. Tak się nie stało, a prezydent wpadł w pułapkę własnych słów. W kwietniu 2013 roku kolejny raz powiedział, że użycie broni chemicznej, będzie zmianą reguł gry ${ }^{15}$, mimo to 21 sierpnia 2013 r. al-Asad zrzucił bombę chemiczną na przedmieścia Damaszku. Relacje $z$ tego ataku okrążyły świat. Co zrobić? Obama powstrzymał się od zdecydowanych działań. Jessica T. Mathews [06.11.2014] oceniała: „Jaskrawą słabością nowej strategii prezydenta Obamy na Bliskim Wschodzie [...] jest brak

ny (np. dotyczące Syrii protokoły dyplomatyczne i publiczne deklaracje przywódców, zapisy audio-wideo i transkrypcje konferencji i debat dotyczących wojny, badania opinii publicznej o wojnie i uchodźcach, wywiady $z$ aktywistami oraz raporty organizacji humanitarnych). Trzeba też pamiętać, że przedstawiony obraz wyłonił się $z$ analizy tylko jednego, choć w wysokim stopniu opiniotwórczego w świecie zachodnim, periodyku.

15 Podczas spotkania z dziennikarzami w Waszyngtonie 20 sierpnia 2012 r. prezydent Obama oświadczył, że rząd Stanów Zjednoczonych przekazał prezydentowi al-Asadowi jasny komunikat: przekroczenie „czerwonej linii”, a więc użycie lub sam zamiar użycia broni chemicznej, będzie miało poważne konsekwencje. Nie wspomniał wprost o interwencji wojskowej, jeśli al-Asad lub ktokolwiek inny jej użyje, powiedział jedynie, że przekroczenie „czerwonej linii” „zmieni jego kalkulacje” i „reguły gry”. 
żołnierzy [ONZ i amerykańskich] na ziemi syryjskiej”. Michael Ignatieff [17.12.2015] przypominał, że interwencja militarna jest uzasadniona wobec państwa, które morduje własnych obywateli. Natomiast David Cole [24.10.2013] bronił Obamy, który zamiast działać natychmiast, zwrócił się do Kongresu o zatwierdzenie akcji militarnej (w ten sposób, mówiono, oddał pole Rosji i al-Asadowi ${ }^{16}$ ). Cole twierdził, że Obama trzymał się po prostu litery Konstytucji Stanów Zjednoczonych, która wymaga, aby wypowiedzenie wojny albo akcja zbrojna wobec innego państwa, były zatwierdzone przez Kongres.

Pasywność Obamy wynikała $z$ dylematów, z którymi musiał się zmierzyć ${ }^{17}$. W listopadzie 2013 roku Mark Danner [07.11.2013] przypomniał duchy Kosowa i Rwandy - trzeba działać, by nie zapełniać ziemi, mówiąc słowami Obamy, „zimną logiką masowych grobów”, a także duchy Iraku i Afganistanu - łatwiej jest zburzyć stary porządek za pomoca bomb, niż zbudować trwały nowy ład; łatwiej jest rozpocząć wojnę, niż ją skończyć. W 2013 roku parlamenty na całym świecie przestały rozmawiać o interwencjach wojskowych, a ministrowie pytani o interwencje odpowiadali: „bez komentarza”. Interwencje pokojowe, zwłaszcza przeprowadzane przez Stany Zjednoczone, o których Micheal Walzer (2006, s. 104) pisał, że niosą pomoc ludziom, którzy nie mają możliwości i zasobów, aby o sobie samych stanowić i że „ilekroć można przerwać brudną robotę, należy do zrobić”, w czasie wojny w Syrii — po porażce „wojny prewencyjnej” w Iraku, straciły moralną legitymizację, a obywatele Stanów Zjednoczonych czuli się zmęczeni rolą ich kraju jako „globalnego policjanta" ${ }^{18}$. Danner [07.11.2013] na łamach NYRB zauważył, że polityka Stanów Zjednoczonych realizowana w Iraku rozmyła alternatywy, a nawet możliwość prowadzenia jakiejkolwiek wiarygodnej, w oczach obywateli Stanów Zjednoczonych i większości sojuszników Ameryki, polityki w Syrii. Ko-

16 Post factum Susie Linfield (NYRDaily [02.09.2019]) stwierdziła, że na początku wojny Obama miał kilka możliwości, każda była zła. Trudno ocenić, czy pasywność prezydenta Stanów Zjednoczonych była wyborem najmniej złym, złym czy bardzo złym. Jedno jest pewne, pisze Linfield, „brak działania był prezentem dla Rosji, Iranu i Hezbollahu”, które włączyły się w wojnę w Syrii z „żarliwą intensywnością, której Zachodowi brakowało”.

17 Nie zdecydował się na użycie sił militarnych w Syrii między innymi dlatego, że sojusznicy Stanów Zjednoczonych, w tym Wielka Brytania, wycofali się z tworzenia międzynarodowej koalicji mającej na celu interwencję wojskową. Nie miał również wsparcia ze strony własnych obywateli pamiętających niedawną wojnę w Iraku.

${ }_{18} \mathrm{Na}$ wojnę w Iraku wydano bilion dolarów, poległo w niej blisko 5000 amerykańskich żołnierzy, 3000 cywilów zostało zabitych tylko w pierwszych czterech tygodniach inwazji. Osłabiła ona też pozycję strategiczną Ameryki na Bliskim Wschodzie 
lejne artykuły w NYRB są utrzymane w tonie porażki politycznej. W ich tytułach pojawia się słowo ludobójstwo, rzeź ${ }^{19}$.

W artykule z 5 grudnia 2013 r. Charles Glass napisał: „wojna osiągnęła etap, w którym po obu stronach konfliktu wielu przestało traktować siebie nawzajem jak ludzi, a tym bardziej jak obywateli państwa, w którym muszą wspólnie żyć". Glass rozmawiał z Mokhtarem Lamani, doświadczonym marokańskim dyplomatą, który powiedział: „wszystko wskazuje, że konflikt zmierza do ludobójstwa". Prawo międzynarodowe zostało wielokrotnie złamane. Przestrzeń cywilna, na którą składają się szkoły, szpitale, miejskie place, została zmilitaryzowana - wyjęta spod międzynarodowego prawa humanitarnego i uznana ze cel ataków. Reżim uzasadniał bombardowanie cywilów tym, że ukrywają rebeliantów. Al-Asad kierował się „strategią drenażu”, czyli wyniszczenia ekonomicznego miast i regionów; bombardowania budynków publicznych, na przykład szkół i szpitali; odcięcia od wody pitnej i środków higieny publicznej czy zaprzestania rutynowych szczepień noworodków. Wyniszczenie życia cywilnego i materialnej podstawy tego życia miało na celu zmuszenie cywilów do ucieczki albo jednoznacznego opowiedzenia się za reżimem i pozostawienia rebeliantów bez „ochrony cywilnej”. Niemal każdy artykuł NYRB o wojnie w Syrii pokazuje — czasami w jednym akapicie, czasami w całym tekście — jak wojna ta sprowadza militaryzację przestrzeni cywilnej chronionej przez prawo międzynarodowe - przestrzeni, której świat zachodni powinien bronić. Tymczasem zachodnia opinia publiczna przestała reagować oburzeniem i szokiem na kurczenie się przestrzeni cywilnej w Syrii (zob. Rapior 2018)

W artykule z 21 listopada 2013 r. Kenneth Roth, szef Human Rights Watch, pytał o sens „czerwonej linii” określającej zakazaną broń: „czerwone światło dla broni chemicznej, zielone dla broni konwencjonalnej”? Zwracał uwagę, że miesięcznie ginie 5000 Syryjczyków (98\% zabitych to ofiary broni konwencjonalnej). W ataku z 21 sierpnia 2013 r. zginęło 1400 osób (2\% ogółu zabitych). Stwierdził, że Zachód reaguje, dyplomatycznie bądź militarnie, zwykle w momentach spektakularnych, tymczasem Syria potrzebuje długotrwałej strategii pokojowej. Być może, pyta Roth, Zachód powinien przemyśleć nie tylko to, jak zareagować na użycie niekonwencjonalnej broni w Syrii, lecz również podstawy i założenia całej swojej polityki międzynarodowej?

19 Wiele tytułów artykułów zawiera pojęcia gęste, czyli takie, które służą jednocześnie do opisu i oceny jakieś sytuacji, osoby, grupy (Abend 2014). Pojawiają się takie słowa jak: „katastrofa”, „ludobójstwo”, „epidemia”, „agonia”, „martwa ziemia”, „destrukcja”. 
W 2014 roku na geopolitycznej scenie pojawiło się ISIS. Amerykanie mogli skierować swoje siły nie na cele reżimowe, ale na wrogów reżimu - ISIS. Dało to al-Asadowi nadzieję na przetrwanie, a Obamie możliwość wycofania się z twarzą ze słów wypowiedzianych w latach 2011-2013. Gdy w Syrii pojawiło się ISIS, Amerykanie mogli uznać, iż al-Asad jest tam potrzebny. W roku 2014 na łamach NYRB artykuły o cywilnych stratach w Syrii zaczynają być wypierane przez te, które dotyczą ISIS - to ono, stanowi teraz największy problem Syrii i świata.

\section{Dylemat Merkel:}

jak czynić dobro nie narażając interesu własnego?

Tymczasem w numerze NYRB z 22 października 2015 r. - tym samym, w którym Charles Glass pytał, co powstrzymuje zachodnie mocarstwa przed interwencją wojskową (lub jakąkolwiek stanowczą reakcją) na okropieństwa wojny w Syrii - ukazał się artykuł Hugh Eakina, w którym czytamy: „nie wiadomo, kiedy Europa ocknie się w obliczu największego ruchu uchodźców od czasów drugiej wojny światowej, ale niedziela 16 sierpnia będzie decydująca". Tego dnia kanclerz Niemiec Angela Merkel wróciła z wakacji i stwierdziła: „największym wyzwaniem dla Unii Europejskiej nie jest już zadłużenie Grecji”. Według Merkel wyzwaniem tym stał się napływ ludzi z Syrii i innych krajów Bliskiego Wschodu i Afryki do państw UE. Sprawa uchodźców będzie absorbować Europę, zauważyła Merkel, bardziej niż stabilność euro. Kanclerz Niemiec, podobnie jak prezydent Stnów Zjednoczonych, uosabia najważniejsze problemy wojny w Syrii: Obama - dylemat związany z potrzebą interwencji militarnej i niechęcią do działania "tam”; Merkel — wahania między obowiązkiem pomocy ofiarom i niechęcią do działania "tu”.

Dylemat Merkel sprowadza się do pytania: czy przyjmować uchodźców u siebie, sprowadzać ich do Europy ${ }^{20}$, realizując w ten sposób zaczerpniętą z dwóch wielkich wojen lekcję, którą można sprowadzić do hasła „nigdy więcej” (Holokaustu, zabroni przeciwko ludzkości - te pojęcia wprowadzono do obiegu prawnego i publicznego w trakcie trwania procesów norymberskich), czy chronić granice państw, a także UE, pod pretekstem, że uchodźcy stanowią zagrożenie dla bezpieczeństwa narodowego, wywołują strach wśród obywateli (są źródłem naruszania porządku publiczne-

\footnotetext{
${ }^{20}$ Ignatieff 17 grudnia 2015 r. na łamach NYRB pisał, że zawieszenie broni albo utworzenie bezpiecznych stref nie załatwią sprawy, znamiona praktycznych działań ma tylko przesiedlenie Syryjczyków do innych krajów.
} 
go), a nawet, jak powiedział prezes partii rządzącej w Polsce, roznoszą „pasożyty” 21. Dylemat Merkel odnosi się też do celu przyjmowania/nieprzyjmowania uchodźców: „czy celem jest danie ludziom szukającym azylu nowego startu w życiu czy zaoferowanie im tymczasowej ochrony podczas kryzysu?".

Dzięki lekturze artykułów w NYRB czytelnik dowie się z jednej strony, że podczas wojny w Syrii pojawiło się wiele spontanicznych działań obywatelskich - dostarczanie wody, żywności, odzieży, schronienia, a nawet propozycje, często nielegalne, przewozu własnym samochodem do kraju UE; drugiej — że w siłę rosły polityczne partie antyemigranckie. Geert Wilders, skrajny prawicowy populista holenderski, zarzekał się, że jesteśmy świadkami ,islamskiej inwazji”. Na dylemat Merkel Niemcy odpowiedziały zaproszeniem szukających azylu - było to widać chociażby na transparentach z napisałem Welcome; Dania natomiast - przypomina Eakin w kolejnym swym artykule [10.03.2016] — wykupiła ogłoszenia w języku angielskim i arabskim w gazetach w Libanie, gdzie przebywało wówczas półtora miliona Syryjczyków, z informacją, by nie przybywali oni do Europy. Policja w Czechach siłą wyciągała uchodźców z pociągów, zdarzyło się, że na ramionach wypisywano im numery. Słowacja oznajmiła, że przyjmie tylko chrześcijan. Na Węgrzech zastosowano przeciwko uchodźcom gaz łzawiący.

David Cameron, angielski premier i lider Partii Konserwatywnej, 7 września 2015 mówił w parlamencie o zagrożeniu dla bezpieczeństwa narodowego ze strony „islamskiej ekstremalnej przemocy”. Mniej więcej w tym samym czasie Andreas Kamm, dyrektor Danish Refugee Concil, powiedział Eakinowi [22.10.2015], że jesteśmy świadkami „światowego konfliktu", w którym główną ofiarą są niemający możliwości ucieczki cywile, i stwierdził: „Dla Europy liczba [przybywających uchodźców] nie jest za wysoka. Gdybyśmy mieli przywódców, którzy umieliby ze sobą współpracować i którzy powiedzieliby, że możemy robić rzeczy lepiej, to dalibyśmy sobie radę - milion uchodźców to tylko $0,2 \%$ europejskiej populacji. Ale jeśli niczego nie zrobimy, ludzie powiedzą «to jest poza kontrolą». I wtedy będzie poza kontrolą. To właśnie mnie przeraża”.

Wniosek, jaki można wyciągnąć $z$ artykułów Eakina, brzmi: politycy wygłaszają płomienne przemówienia na konferencjach, ale mają problem

${ }^{21}$ Donald Trump, wówczas kandydat republikanów na urząd prezydenta Stanów Zjednoczonych, ochrzcił uchodźców z Syrii mianem „konia trojańskiego”. W lipcu 1942 roku Albert Einstein pisał do Eleonor Roosevelt o „biurokratycznej ścianie”, która nie pozwala chronić ofiar faszyzmu w Europie. Jego list nie wywarł wielkiego wpływu. Strach, że uchodźcy okażą się szpiegami, był ważniejszy niż fakty — ponad dwa i pół miliona zabitych Żydów w 1942 roku (Miliband [13.10.2016]). 
z budową wspólnoty, w której przywódcy i obywatele mieliby wspólne interesy i cele. Można też dostrzec, że pojawił się problem definicyjny. Merkel i Jean-Claude Juncker mówili o „uchodźcach”, inni przywódcy krajów UE o „migrantach”, a nawet „nielegalnych migrantach” — słowa, które całkowicie zaciemniają grozę wojny w Syrii, podkreśla Eakin. Podobne zamieszanie pojawiło się w prasie: brytyjski „Guardian” pisał o „uchodźcach”, a amerykański „New York Times” o „migrantach”. Powszechnie uważano, że Merkel ryzykuje stratę władzy, jeśli nie pokaże, iż panuje nad granicami. Dlatego w obozach dla uchodźców, zwykle powojskowych barakach, Syryjczyków oddzielano od Albańczyków, Serbów, Macedończyków, Pakistańczyków, Afgańczyków, Somalijczyków, Erytrejczyków, Libańczyków. Choć członkowie pięciu ostatnich wymienionych nacji twierdzili, podobnie jak Syryjczycy, że uciekają przed śmiercią, mieli wrócić do własnych krajów. Decyzja kto jest „migrantem”, a kto „uchodźcą" okazuje się arbitralna.

$\mathrm{O}$ atakach ISIS w Ankarze, Bejrucie i Paryżu Ignatieff napisał na łamach NYRB [17.12.2015], że są „kampanią strategicznej dezinformacji”. Mają na celu wywołanie strachu, zagubienia, utraty zdolności orzekania, co jest czym. Ignatieff sądzi, że Europa powinna być silna wartościami, które od dziesiątków lata stanowią jej podstawę. Przede wszystkim nie wolno, twierdzi kanadyjski profesor, przyjmować reguł gry ISIS i godzić się na propozycje prawicowej demagożki Marine Le Pen, które zasugerowała, że Francja musi masowo deportować imigrantów, twardo przesłuchiwać podejrzanych, pozbawiać wolności bez sądu czy skończyć ze swobodnym przepływem ludzi w Europie. Państwa europejskie nie powinny wyzbywać się humanizmu, powinny udzielać pomocy tym, którzy uciekają przed barbarzyńcami. Ignatieff nawiązuje w ten sposób do fundamentalnego pytania Hannah Arendt: „kto ma prawo mieć prawo?”. Redefinicja praw człowieka po 1945 roku miała za zadanie nadać prawa bezpaństwowcom, którzy nie mają ochrony prawnej, gdyż nie przynależą do żadnego państwa, tak jak Arendt po 1933 roku. Dylemat Merkel jest więc ściśle związany z kwestą obywatelstwa i pytaniem: kto w moim kraju ma prawo mieć prawo?

Dylemat humanitaryzmu:

jak tworzyć długofalową politykę na rzecz pokoju, zachowując zasadę neutralności?

Humanitaryzm nie jest jedynym dyskursem wpływającym na to, jak zachodnia publiczność odbiera i rozumie problemy społeczne $z$ dalekich miejsc. Równie ważne są pomoc rozwojowa i prawa człowieka. Powszech- 
nie oddziela się jednak politykę i prawa od dobroczynności (zob. Krause 2014). Pomoc humanitarna ma uśmierzyć ból, a nie kształtować długofalową politykę. „Według prawa humanitarnego przestrzenie humanitarne powinny być wolne od jakichkolwiek interesów politycznych i militarnych" (Polman 2011, s. 254). Podstawową zasadą humanitaryzmu jest więc zachowanie neutralności i niesienie pomocy wszystkim potrzebującym, niezależnie od wszystkich innych kwestii (zwłaszcza politycznych). Na łamach NYRB zasada neutralności humanitaryzmu zostaje sproblematyzowana.

Michael Ignatieff [17.12.2015] podkreśla, że konwencja uchodźcza z 1951 roku nie stosuje się do współczesności. Ludzie z Syrii uciekają nie przed prześladowaniem, lecz przed śmiercią. Otwarte granice i łatwy dostęp do internetu powodują, że ofiary nie są zamknięte wewnątrz granic państwa totalitarnego, mogą przedostać się do innego kraju albo przesłać dowody zbrodni reżimu. Ignatieff zauważa, że pomoc rozwojowa ma nowe oblicze: kontrola migracji. Twierdzi, że polityka poprawiania warunków życia biednych krajów wynika dziś nie tyle z ideologii modernizacji, ile z potrzeby zatrzymania mieszkańców tych krajów na miejscu ${ }^{22}$. Kanadyjczyk przekonuje, że polityka powinna oddziaływać dwubiegunowo, i podaje przykład Stanów Zjednoczonych - powinniśmy, pisze, przyjąć uchodźców, o których mówi UNHCR, ale także wzmacniać instytucje państwowe Meksyku czy Hondurasu (dostęp do bieżącej wody, prądu, opieki zdrowotnej, szkolnictwa) oraz walczyć z gangami i zabójstwami w tych krajach. Mówiąc inaczej, ochrona warunków życia cywilnego w krajach ubogich nie powinna oznaczać braku wsparcia dla ludzi, którzy już swój kraj opuścili.

W ostatnich latach syryjskiego konfliktu David Miliband [13.10.2016] ocenił, że międzynarodowa odpowiedź na potrzebę schronienia wzrastającej liczby uchodźców była niedostateczna pod trzema względami: (1) finasowanie było niewystarczające (w 2015 roku ONZ apelowało o $20 \mathrm{mld}$ dolarów na pomoc humanitarną, otrzymało tylko 11); (2) bogate państwa, z wyjątkiem Niemiec, nie przyjęły wystarczającej liczby uchodźców; (3) przeważała wiara w fikcję, że uchodźcy potrzebują pomocy doraźnejpomoc zwykle jest tymczasowa i nie wiąże lub bardzo luźno wiąże się ona z długotrwałymi działaniami politycznymi oraz z długofalową perspektywą czasową. Tymczasem, jak podawał Miliband, w 2014 roku 90\% krajów ubiegających się o pomoc humanitarną starało się o nią przez trzy lub

22 UE ogłosiła w 2015 roku, że przekaże dodatkowy miliard euro krajom afrykańskim na wzmocnienie ich granic, a także na reformę instytucji państwowych i lepsze przestrzeganie praw człowieka. 
więcej kolejnych lat (60\% dłużej niż osiem lat). Organizacje humanitarne realizują projekty krótkoterminowe. Na przykład średnia długość grantu z International Rescue Committee (instytucja nadzoruje około siedmiuset projektów w jednym czasie) to dwanaście miesięcy. Darczyńcy zwykle biorą pod uwagę planowanie krótkoterminowe, a działania długoterminowe są niedofinansowane.

Połączenie humanitaryzmu i modernizacji powinno, według Milibanda, polegać na czterech zasadach: (1) zwiększenie przekazu gotówki do rąk własnych potrzebujących - niech sami zdecydują, na co je wydać; (2) traktowanie uchodźców jak osoby produktywne, a nie biernych mieszkańców obozów; (3) wspomaganie najefektywniejszych programów pomocowych, co oznacza potrzebę ich ewaluacji oraz kierowanie się nie intuicją, lecz danymi; (4) kraje zmagające się z kryzysem humanitarnym powinny skoncentrować się na ograniczonej liczbie konkretnych i mierzalnych celów, które organizacje humanitarne są w stanie zrealizować. Propozycja Milibanda przesuwa akcent na długotrwałe działania, pozostaje jednak strategią odgórną i nieuwzględniającą aspektu politycznego. Czy można połączyć ze sobą interesy polityczne i humanitaryzm? Czy działania odgórne (top-down) wykluczają działania oddolne (bottom-up)? Te dwa pytania składają się na dylemat humanitaryzmu.

Molly Crabapple [06.12.2018] przedstawiła oddolne strategie realizowane przez wolontariuszy, którzy nie wierzą w „dobroczynność”, ale w „solidarność" 23. Pomagali oni w obozie uchodźców pod Calais w 2015 roku. Wolontariusze ci nie nosili koszulek z logo organizacji, nie mówili o „beneficjentach”, nie byli postrzegani przez uchodźców jako „pobierający wysokie wynagrodzenie”, przesiadujący w klimatyzowanych pomieszczeniach pracownicy międzynarodowych NGO-sów. Zamiast tego była kuchnia typu do it yourself i wspólne mecze szachowe między wolontariuszami a afgańskimi dziećmi. Stwarzało to też problemy. Crabapple przypomniała czytelnikom NYRB, że wolontariusze pomagający uchodźcom i emigrantom przybywającym do Europy i do Stanów Zjednoczonych byli i są kryminalizowani przez instytucje państwowe - przeszukiwano ich, stosowano wobec nich przemoc, zatrzymywano i więziono.

W artykułach Milibanda i Crabapple pojawia się wątek poszukiwania nowych strategii pomocy humanitarnej. Problemem nie jest to, czy są

\footnotetext{
${ }^{23}$ Wzmacniając głos Crabapple, można przywołać nie tylko krytykę zasadności kierowania się mierzalnymi celami (Leszczyński 2016), ale też logikę dobroczynności. Większość projektów humanitarnych - pisze Monika Krause (2014) — profilując cele, kieruje się nie kryterium „największej potrzeby”, ale „wykonalności”.
} 
one „odgórne” czy „oddolne”, ponieważ z treści artykułów można wyczytać coraz większą świadomość potrzeby połączenia logiki humanitaryzmu (Polman 2011) i działania lokalnego. Problemem jest niezdolność państwa do dostrzeżenia współpracowników w oddolnych obywatelskich działaniach. Mówiąc inaczej, problemem jest połączenie pomocy humanitarnej $z$ długofalową polityką.

Dylemat państw: jak ograniczyć własną suwerenność, w pełni z niej nie rezygnując?

Suwerenność stanowi podstawę nowoczesnej koncepcji władzy, która jest ucieleśniona w organizacjach terytorialnych zwanych „państwami” bądź „narodami” (Jakson 2011). Kategoria ta jest stale obecna w dyskusjach nad kształtem stosunków międzynarodowych - w ostatnim półwieczu zwłaszcza w kontekście problemu ruchów antykolonialnych (choć państwa postkolonialne nigdy nie zerwały kontaktów z byłymi imperiami), powstania ponadnarodowych organizacji, takich jak UE (choć państwa wchodzące w skład UE nie przestały być państwami), Brexitu (choć związki Wielkiej Brytanii z UE prawdopodobnie pozostaną silne) czy dążeń niepodległościowych Katalończyków (choć Hiszpania zawsze będzie silnym punktem odniesienia dla Katalonii) i Kurdów (choć największe grupy Kurdów żyją na terytorium trzech państw - Syrii, Iraku, Iranu i Turcji). Nie miejsce tu, aby szerzej opisywać tę kategorię. Chcę jedynie zwrócić uwagę, że wojna w Syrii jest istotnym puntem wyjścia do pracy teoretycznej nad klasyczną definicją suwerenności (supreme authority within a territory; zob. Philpott 2016).

Filozofowie, dziennikarze, reporterzy, aktywiści przez ponad osiem lat wzywali na łamach NYRB polityków i światowe potęgi, zwłaszcza Stany Zjednoczone i Unię Europejską, aby cokolwiek zostało zrobione w sprawie Syrii. Nikt - żadna $z$ sił wewnętrznych uczestniczących w wojnie ani żaden $z$ interwentów - nie chce wziąć odpowiedzialności za to, co stało się i dzieje się w tym kraju. Samookreślenie się w roli odpowiedzialnego wiąże się nie tyle $z$ przeprowadzeniem interwencji zbrojonej - ten temat zdominował artykuły NYRB w pierwszych latach wojny - lecz z refleksja nad własnymi interesami państwowymi. Roth [22.12.2016] przypomina, że rządy brytyjskie i francuskie zgodziły się na udział Rosoboronexport, oficjalnego eksportera broni rosyjskiej, w targach uzbrojenia pod Londynem i Paryżem. Twierdzi, że Moskwa nie czuje na sobie międzynarodowej presji, by wpłynąć na al-Asada. Joost Hiltermann [21.12.2017] sądzi, że Rosja nie zawiedzie swoich „klientów” i zakaże stosowania broni chemicz- 
nej reżimowi syryjskiemu dopiero wtedy, gdy będzie pewna, że ów „klient” jest bezpieczny.

Jessica T. Mathews [06.11.2014] pokazała, że na wojnę w Syrii nakładają się „wojny zastępcze”: Stany Zjednoczone versus Rosja; teokracja sunnicka w Arabii Saudyjskiej i Katarze versus teokracja szyicka w Iranie; Turcja versus arabscy nacjonaliści, którzy obawiają się odbudowy imperium sprzed pierwszej wojny światowej. Ani Iran, z którego zdaniem al-Asad się liczy, ani Arabia Saudyjska, która jest sprzymierzeńcem Stanów Zjednoczonych, nie będą dążyły do zawieszenia broni, jeśli nie będą przekonane, że któraś ze stron - sunnici albo szyici - będzie miała przewagę. Mathews przywołuje słowa Yezida Sayigh, profesora i badacza Biskiego Wschodu, który twierdził, że obie strony, reżim i umiarkowana opozycja, nie powinny wpisywać się w amerykańską strategię „najpierw podpisane porozumienie, potem wstrzymanie ognia", lecz równolegle, choć osobno, ogłosić rozejm. Osiągnięcie porozumienia wydaje się nieprawdopodobne. Może je oddalić na przykład porażka rozmów Stanów Zjednoczonych z Iranem na temat broni nuklearnej (zob. Mathews [23.11.2017]) albo niemożność znalezienia wspólnego gruntu przez różne grupy opozycjonistów ${ }^{24}$. Nie wiadomo też jak rozbroić Syrię. Graniczy ona z Izraelem, który jako jedyne państwo na Bliskim Wschodzie dysponuje bronią jądrową. O ponad dwustu głowicach nuklearnych Izraela za wiele się publicznie nie mówi, jednak są one faktem i ważnym argumentem w rozmowach o „broni masowego rażenia”, czy to broni chemicznej w Syrii lub Iraku, czy programu nuklearnego w Iranie.

Sytuacja w Syrii jak najdobitniej pokazuje, że pojęcie suwerenności nie odnosi się dziś do monopolu na sprawowanie władzy wewnątrz granic państwa narodowego. Reżim dysponuje siłami wojskowymi, ale żołnierze wraz z bronią przechodzą na stronę rebeliantów; kontroluje telewizję i media, lecz nie wiadomości o zbrodniach przekazywane przez cywilów za pośrednictwem internetu. Kurdowie organizują własne odziały, które mają ich bronić przed reżimem i innymi grupami militarnymi. Państwo nie ma monopolu na stosowanie przemocy na całym terytorium i próbuje go odzyskać przez nielegalne akcje i łamanie prawa międzynarodowego, na przykład umieszczając snajperów na dachach budynków, by strzelali do cywilów. W Syrii istnieje wiele używających przemocy grup, wspieranych przez siły zewnętrzne.

${ }^{24}$ Niektórzy twierdzą, że al-Asad musi ustąpić, inni zaś, że chcą spróbować stworzyć w nowej Syrii ramy pokoju z jakąś, mniejszą lub większą, rolą al-Asada, ponieważ nie wierzą w możliwość jego odejścia. 
Wnioski płynące $z$ analizy artykułów w NYRB są następujące: musimy na nowo przemyśleć pojęcie suwerenności. Syria jest przykładem tego, że suwerenność nie oznacza niezależnego sprawowania władzy politycznej na określonym terytorium. Okazuje się, że suwerenność przejawia się w stabilnych porozumieniach, układach, koalicjach, procedurach. Żadne państwo, ani Syria, ani Stany Zjednoczone, ani Rosja; żadna organizacja międzynarodowa, ani UE, ani ONZ, nie ma środków i władzy, by samodzielnie działać skutecznie i ograniczyć szkody wojen, konfliktów, katastrof. Suwerenność objawia się w zbiorowej umiejętności radzenia sobie z kryzysami. Tony Judt niegdyś twierdził, że będziemy zmuszeni działać za pośrednictwem innych, wzajemnie współpracujących, bez oglądania się na różne interesy narodowe i granice, które i tak stracą wiele ze swego znaczenia. Zdaniem amerykańskiego dyplomaty Richarda N. Haassa dzisiejszą Realpolitik lepiej opisuje termin „obowiązek suwerena” (państwa mają zobowiązania wobec jednostek i państw poza swoim terytorium) niż tradycyjne podejście - „odpowiedzialność suwerena” (państwo jest odpowiedzialne za własnych obywateli i warunki wewnątrz swoich granic) (zob. Mathews [09.02.2017]). Granice nie znikną, ale są porowate i żadne mury ich nie uszczelnią. Suwerenność, jak pokazuje sytuacja w Syrii i jej konsekwencje, to sztuka kompromisów i działania „za pośrednictwem”, a nie niezależność od innych.

\section{Dylemat Colvin:}

jak być usłyszanym, gdy nikt nie słucha?

Dziennikarz brytyjski Ed Vulliamy [20.12.2018] przywołał słowa znanej reporterki Marie Colvin, która zginęła w Syrii. Przywódcom Wolnej Armii Syrii mówiła: „świat desperacko potrzebuje zobaczyć, co dzieje się w Baba Amr [...] my możemy to pokazać, możemy być świadkami”. Colvin powtarzała, że zbrodnie muszą zostać pokazane światu, że dzięki świadectwu „zrobimy różnicę”. Vulliamy przypomina, jak w lecie 1992 roku odkrył obozy koncentracyjne w Bośni. Opowiedział o nich światu. „Politycy chuchali i dmuchali, ale nic się nie wydarzyło przez trzy krwawe lata, aż do masakry ośmiu tysięcy w Srebrenicy w 1995”. Czasami świetni dziennikarze „nie robią żadnej różnicy”.

Podobnie jak Colvin opowiedziała się w tej kwestii Molly Crabapple [06.12.2018], przypominając pytanie usłyszane od młodego Palestyńczyka imieniem Walid, który często opowiadał reporterom swoją historię wygnania: „Czy sądzisz, że te artykuły zrobią cokolwiek?”. „Nie — odparła Crabapple po chwili zastanowienia - ale ważne jest, by dokumentować". 
Charles Glass [22.10.2015] z kolei wyrażał dezaprobatę: „Czterdzieści cztery strony straszliwych zbrodni wojennych raportu ONZ [Report of the Independent International Commission of Inquiry on the Syrian Arab Republic] powinno wystarczyć zewnętrznym mocarstwom, by drgnać i wezwać do zakończenia tej wojny. Na co oni czekają?”. Przypomniał też zdjęcie kurdyjskiego chłopca Alana Kurdi, którego ciało morze wyrzuciło na brzeg Turcji. Czy raporty i zdjęcia mają taką moc, by wezwać przywódcy mocarstw by „drgnęli i wezwali do zakończenia wojny”?.

Nadzieją fotografii wojennej od początku jej istnienia było to, że świat widząc okropności wojny, podejmie, to co Martha Gellhorn nazwała „akcjami ratunkowymi" (Linfield [NYRDaily 09.02.2019]). Wojna w Syrii poddała testowi tradycyjną funkcję fotografii wojennej ${ }^{25}$. Rozmawiając o fotografii, nie można bowiem oderwać obrazu od sposobu jego produkcji, dystrybucji i archiwizowania. Fotografia sama w sobie nie jest przyczyną działania. Zdjęcie kurdyjskiego chłopca nie pojawiły się w próżni. Krótkotrwała reakcja na szok wywołany tym zdjęciem (np. wpłaty na szwedzki Czerwony Krzyż były pięćdziesiąt pięć razy wyższe w tygodniu po ukazaniu się zdjęcia niż w poprzednim [214300 dol., a 3850 tydzień później], w następnych stopniowo malały) jest charakterystyczna dla zachodnich społeczeństw (Slovic i in. 2017). Wpłacanie datków jest dziś powszechnym sposobem rozumienia pomagania — łatwym, szybkim, niewymagającym poświęceń i uspokajającym sumienie. Namawiają do niego nie tylko organizacje humanitarne, ale też filozofowie, jak Peter Singer. Zdjęcia na rynku humanitarnym są przy tym istotnym elementem mobilizowania darczyńców. Logika pomocowa wymaga ich istnienia. Organizacje pomocowe realizują projekty, a zasoby są ograniczone (zob. Krause 2014). Ofiarodawcy organizacji pomocowych są bardzo różnymi ludźmi, wyznającymi różne religie, wartości, tradycje. Zdjęcie chłopca łączy ich wszystkich — dziecko jest rozumiane jako niewinne, bezbronne. Jest „człowiekiem”, bez kultury, klasy społecznej, religii. Taki dyskurs niewinności, w połączeniu ze zdjęciem bezwładnego chłopięcego ciała obmywanego przez fale,

${ }^{25}$ Kilka lat temu napisałem tekst Widzieć. Działać (Rapior 2012), w którym dowodziłem, że zdjęcia, reportaże, działania artystyczne mogą zawstydzić decydentów i pobudzić sumienia mieszkańców Zachodu, by wywarli presję na politykach. Pisałem, że zdjęcia mogą zmobilizować nas do utożsamienia się z ofiarami wojny, a następnie do podjęcia działania na rzecz pokoju. Po analizie artykułów z NYRB, stwierdzam, że mój esej był znakiem czasów, w których powstawał. Między 2012 a 2019 rokiem pojawiło się wiele dylematów, które spowodowały, iż wzór reakcji na cudze cierpienie „widzieć-działać” przestał być oczywisty. Wielu komentatorów współczesności wskazuje, że konsensus liberalny dobiegł dziś końca (Snyder 2019; Runciman 2018). Pytają, jaki świat wyłoni się w jego miejsce? 
a także logiką pomocy humanitarnej, motywuje do zrobienia czegoś bardzo typowego - wpłacania datków.

Wiele o okrucieństwach wojny w Syrii wiemy od samych sprawców. ISIS przekazywało $\mathrm{w}$ internecie na żywo egzekucje dziennikarzy i innych zakładników albo spalenie żywcem jordańskiego pilota. Reżim al-Asada dokumentował działania wojenne, zdjęcia zbrodni robił między innymi „Cezar”, fotograf z Damaszku, który dziś żyje w północnej Europie w ramach programu ochrony świadków. Gdy wybuchła wojna, otrzymał zlecenie sfotografowania cywilów z Dera. Powiedziano mu, że jedzie sfotografować ciała terrorystów. W przeciwieństwie do amatorskich zdjęć i filmów kręconych smartfonem przez syryjskich aktywistów albo cywilów zdjęcia Cezara i innych oficjalnie zatrudnionych fotografów są metodyczne. Korpus fotografowany jest kilka razy: twarz, całe ciało, $z$ boku, głowa i ramiona, same nogi. Ciała często są zastygłe w przerażeniu i cierpieniu mówi Cezar - z otwartymi ustami, zalane jeszcze ciepłą krwią, z połamanymi zębami i ropiejącymi ranami. To, co widzimy jest prawdą, ale nie całą prawdą, dlatego wciąż potrzebujemy dziennikarzy i fotoreporterów wojennych - by mieć sprawiedliwy ogląd sytuacji.

Postmodernistyczni krytycy zarzucali fotografii rozmywanie prawdy i manipulację (Linfield 2013), ponieważ nie tłumaczy ona kontekstu politycznego, lecz pokazuje anonimowe ofiary oraz przyzwyczaja do widoku cierpienia. W latach osiemdziesiątych XX wieku zdekonstruowano romantyczną więź łączącą politykę i zdjęcia oraz mityczną postać korespondenta wojennego jako bohatera albo męczennika. Zdjęcia szokują, ale tylko na chwilę - uspokajamy sumienie, wpłacając datki na organizację pomocową. Zblazowanie i szok na ich widok to dziś dwie powszechne reakcje (Sontag 2010), co dowodzi nieskuteczności zdjęć i relacji z miejsc objętych konfliktem.

Publikujący w NYRB polemizują z takim poglądem. Jest w nich wiara w potrzebę rzetelnego dokumentowania wojny, ale skuteczność fotografii, a także raportów i relacji dziennikarskich, widzą nie w dekonstrukcji czy dystansie do obrazu bądź w bezpośredniej reakcji na wizerunek, lecz w budowaniu myślenia długofalowego. Mówiąc inaczej - we wspieraniu myślenia historycznego, a nie wytwarzania „wiecznej teraźniejszości" (Snyder 2019). Zdjęć i reportaży mogą się do tego przyczynić poprzez:

— dostarczanie dowodów zabroni (choć, jak twierdzi Glass, na razie większy użytek z tych świadectw czynią historycy niż sędziowie) — „bycie tam na miejscu" pozostało wciąż najważniejszym budulcem dziennikarskiego autorytetu; 
- utrwalanie wartości takich jak wiarygodność, prawdomówność, bezstronność - chaos nie oznacza, iż nie można ustalić prawdy ${ }^{26}$;

- umacnianie wiary w historię i długotrwałą dyskusję, która nie kończy się po wpłaceniu datku na organizację pomocową.

Rzetelne reportaże, zdjęcia, filmy, raporty stają się częścią naszej przyszłości - następne pokolenia otrzymają je od nas w spadku i będą mogły wynieść $z$ nich lekcje. Niezależne ustalenie faktów jest niezbędnym warunkiem powodzenia powojennych wysiłków na rzecz przywrócenia i zawarcia międzynarodowego porozumienia w sprawie użycia broni chemicznej. Jest to szczególnie ważne w czasach, gdy fake news mogą w decydujący sposób kształtować społeczne zrozumienie zbrodni wojennych.

Chociaż bywa, że świetni dziennikarze „nie robią żadnej różnicy”, jak pisał Vulliamy, to raporty, reportaże i fotografie zachowują to, co utracone — życie ludzkie.

\section{WNIOSKI KOŃCOWE}

Dylematy, które opisałem, wskazują na ewolucję zachodniego podejścia do sprawiedliwości globalnej. Do lat dziewięćdziesiątych XX wie$\mathrm{ku}$, nie zajmowano się kwestią stosunku sprawiedliwego społeczeństwa (Rawls 1994) do innych społeczeństw i obywateli innych krajów (zob. Mandle 2009). Później zaczęto pytać o wojnę sprawiedliwą i warunki konieczne do przeprowadzenia usprawiedliwionej interwencji pokojowej (Walzer 2006). Jednak konflikt syryjski podważył tradycyjne przekonania na temat dobra i zła, ofiar i sprawców (Swaan 2015). W 2015 roku Ignatieff [17.12.2015] pisał, że w Syrii nie ma „pozytywnych bohaterów”, którzy uszlachetnialiby humanitarną akcję ratunkową w oczach zachodniej opinii publicznej. Na Syrię opadła „mgła wojny” (Rapior 2018, s. 121-122) - przekonanie, że wojna jest tak złożona, że nie można określić, kto zrzucił bombę chemiczną, kto jest ofiarą, a kto sprawcą. Jednocześnie obrazy przedstawiające mordy na ludności cywilnej - przerażały. W Syrii zapanował chaos - poczucie, że fakty po prostu się zdarzają, kierują nimi abstrakcyjne siły, nad którymi nie ma kontroli. Nie trzeba wówczas

${ }^{26}$ Niezależne wyspecjalizowane organizacje, takie jak OPCW (Organizacja ds. Zakazu Broni Chemicznej), komisja ONZ i organizacje pozarządowe, usilnie pracują nad ustaleniem faktów. Przeprowadzają wywiady z naocznymi świadkami (w tym $z$ ofiarami i personelem medycznym), zbierają i analizują dowody (w tym próbki biomedyczne ze zwłok ludzi i zwierząt, próbki środowiskowe oraz pozostałości po minach i detonatorach) oraz badają zdjęcia satelitarne, rejestry lotów i inne materiały pierwotne. Praca taka nie może być wykonana szybko. 
rozmawiać o wizji dobrego życia w Syrii, o tym, co zrobić z wściekłością i nienawiścią drzemiącą w młodych Syryjczykach, którzy nie mają o czym wspominać swoim dzieciom ${ }^{27}$. Nie trzeba pytać, czy my, obywatele Polski i UE, jesteśmy odpowiedzialni za wspólny świat.

Ów chaos na potrzeby czytelników NYRB próbowali uporządkować korespondenci wojenni, dziennikarze, reportażyści. Podkreślali, że idee są ważne. Mieli na myśli konkretne idee - liberalne. Liberałowie angażują się na „rzecz prawa międzynarodowego, negocjacji i doniosłości moralnego świadectwa" - pisał Judt (2011, s. 450-451). Wszystko to stanowi podstawę dylematów, o których pisałem. Jednak obraz, który wyłonił się w wyniku analizy artykułów w NYRB nie jest zredukowany do opozycji („demokracja kontra totalitaryzm” albo „wolność kontra faszyzm”), ale okazuje się złożony, a nawet niejasny. Niektórzy autorzy zachęcali do konkretnego działania (jak Ignatieff, który propagował interwencję militarną), inni byli przeciwni (jak Cole, który usprawiedliwiał decyzję Obamy, by wstrzymać się z interwencją zbrojną). Liberalizm nie ma dziś jasnych odpowiedzi na międzypaństwowe problemy — taki narzuca się wniosek. Podstawowym sposobem myślenia liberalnego - przynajmniej takiego, jakie można znaleźć w NYRB - jest dziś rozstrzyganie dylematów. Powoduje to, że stajemy przed koniecznością wyboru. Zabranie głosu nie oznacza zatem powtarzania ogólnych prawd, ale odpowiedzialność za swój wybór.

Opisane dylematy składają się na matrycę myślenia o naszych relacjach $z$ innymi, określają, co trzeba brać pod uwagę, kogo można popierać, kogo opłakiwać. Wyznaczają również zadania dla nauk społecznych:

— zdefiniowanie na nowo pojęcia odpowiedzialności politycznej i interwencji pokojowej (dylemat Obamy);

- rozszerzenie kategorii obywatelstwa (dylemat Merkel);

— określanie związków humanitaryzmu z globalną polityką (dylemat humanitaryzmu);

— określenie granic suwerenności państw i organizacji ponadpaństwowych (dylemat państw);

- praca nad sposobami wytwarzania, dystrybucji i odbioru świadectw zbrodni (dylemat Colvin).

27 Wielu Syryjczyków, także za granica, straciło swoich mężów, żony, dzieci, bliskich, przyjaciół, cały dobytek; sami byli torturowani, zabrano im marzenia, zdruzgotano ich godność. Nienawiść stała się elementem mentalności wielu z nich. I nie powinno nas to dziwić, pisała Lindsey Hilsum [23.11.2017]. 
Nie mniej istotne powinno być zrozumienie powiązań prawa międzynarodowego $z$ intuicjami zwykłych ludzi, którzy boją się nieznanego, a także określenie, czym jest doniosłość świadectwa moralnego w dobie globalnie dostępnego internetu, i jak możliwa jest ciągłość historyczna w czasach, w których wierzymy w skuteczność krótkotrwałych interwencji.

\section{BIBILOGRAFIA}

Autesserre Séverine, 2019, The Crisis of Peacekeeping: Why the UN Can't End Wars, „Foreign Affairs", t. 98(1).

Abend Gabriel, 2014, The Moral Background: An Inquiry into the History of Business Ethics, Princeton University Press, Princeton.

Butler Judith, 2011, Ramy wojny. Kiedy życie godne jest opłakiwania?, tłum. Alina Czarnacka, Książka i Prasa, Warszawa.

Drozdowski i in., 2014, Praktyki kulturalne Polaków, Wydawnictwo Naukowe Uniwersytetu Mikołaja Kopernika, Toruń.

Hashemi Nader, Postel Danny (red.), 2013, The Syria Dilemma, The MIT Press, Cambridge, MA.

Heidrich Dorota, 2013, Zasada odpowiedzialności za ochronę i możliwość jej praktycznego zastosowania. Casus Libii, „Stosunki Międzynarodowe”, t. 47(1), s. 167-190.

Jakson Robert, 2011, Suwerenność, tłum. Jakub Majmurek, Sic!, Warszawa.

Jomma Fuad, 2018, Wptyw podziałów religijnych, narodowych i etnicznych na procesy polityczne w Syrii, Wydawnictwo Naukowe Uniwersytetu Szczecińskiego, Szczecin.

Judt Tony, 2011, Zapomniany wiek dwudziesty. Retrospekcje, tłum. Paweł Marczewski, Wydawnictwa Uniwersytetu Warszawskiego, Warszawa.

Judt Tony, 2015, Kiedy zmieniaja się fakty. Eseje 1995-2010, tłum. Andrzej Jankowski, Rebis, Poznań.

Kaufmann Jean-Claude, 2010, Wywiad rozumiejacy, tłum. Alina Kapciak, Oficyna Naukowa, Warszawa.

Kaufmann Jean-Claude, 2013, Kiedy Ja jest innym. Dlaczego ijak się cośw nas zmienia, tłum. Alina Kapciak, Oficyna Naukowa, Warszawa.

Krause Monika, 2014, The Good Project: Humanitarian Relief NGOs and the Fragmentation of Reason, University of Chicago Press, Chicago.

Leszczyński Adam, 2016, Eksperymenty na biednych. Polityczny, moralny i ekonomiczny spór o to, jak pomagać skutecznie, Wydawnictwo Krytyki Politycznej, Warszawa.

Linfield Susie, 2013, A Little History of Photography Criticism; or, Why Do Photography Critics Hate Photography?, Chicago Shorts, Chicago.

Mandle Jon, 2009, Globalna sprawiedliwość, tłum. Małgorzata Dera, Sic!, Warszawa.

Philpott Daniel, 2016, Sovereignty, w: Edward N. Zalta (red.), The Stanford Encyclopedia of Philosophy (https://plato.stanford.edu/archives/sum2016/entries/sovereignty [31.03.2019]).

Polman Linda, 2011, Karawana kryzysu. Za kulisami przemysłu pomocy humanitarnej, tłum. Ewa Jusewicz-Kalter, Czarne, Wołowiec.

Rapior Waldemar, 2012, Widzieć. Działać. Kilka uwag o wspótczuciu, w: Waldemar Rapior, Anna R. Burzyńska (red.), Wyostrzyć wzrok. J.M. Coetzee: sztuka, świat i polityka, Fundacja Malta-Homini, Poznań-Kraków. 
Rapior Waldemar, 2018, Kim jest cywil?, „Kultura Współczesna”, nr 2.

Rawls John, 1994, Teoria sprawiedliwości, tłum. Maciej Panufnik, Jarosław Pasek, Adam Romaniuk, Wydawnictwo Naukowe PWN, Warszawa.

Runciman David, 2018, How Democracy Ends, Basic Books, New York.

Slovic Paul, Västfjäll Daniel, Erlandsson Arvid, Gregory Robin, 2017, Iconic Photographs and the Ebb and Flow of Empathic Response to Humanitarian Disasters, Proceedings of the National Academy of Sciences USA, nr 114, s. 640-644 (DOI: 10.1073/pnas.1701230114).

Snyder Timothy, 2019, Droga do niewolności. Rosja, Europa, Ameryka, tłum. Bartłomiej Pietrzyk, Znak Horyzont, Kraków.

Sontag Susan, 2010, Widok cudzego cierpienia, tłum. Sławomir Magala, Karakter, Kraków.

Swaan Abram de, 2015, The Killing Compartments: The Mentality of Mass Murder, Yale University Press.

Walzer Michael, 2006, Spór o wojnę, tłum. Zofia Zinserling, Muza, Warszawa.

Wilk Wojciech, 2019, Wojna w Syrii zaczęła się od zmian klimatycznych, wywiad Marcin Wyrwał, one.pl, 15 marca (https://wiadomosci.onet.pl/tylko-w-onecie/wojna-w-syrii-wywiad-zwojciechem-wilkiem/6kyj2kw [31.03.2019]).

\section{Korpus analizowanych tekstów}

[według kolejności ukazywania się w „New York Rewiev of Books”]

[09.06.2011] Malise Ruthven, Storm over Syria.

[07.06.2012] Charles Glass, Syria: The Citadel \& the War.

[27.08.2012] Max Rodenbeck, The Agony of Syria.

[08.11.2012] Hussein Agha, This Is Not a Revolution.

[20.12.2012 ] Charles Glass, Aleppo: How Syria Is Being Destroyed.

[20.06.2013] David Bromwich, Stay Out of Syria!

[21.09.2013] Kenneth Roth, Syria: What Chance to Stop the Slaughter

[10.10.2013] Hugh Eakin, Syria's Refugees: The Catastrophe.

[24.10.2013] David Cole, Syria: The New Turn.

[07.11.2013] Mark Danner, Syria: Is There a Solution?

*[21.11.2013] Mark Lilla, Arendt \& Eichmann: The New Truth.

[05.12.2013] Charles Glass, Syria: On the Way to Genocide?

[20.02.2014] Annie Sparrow, Syria's Polio Epidemic: The Suppressed Truth.

[06.11.2014] Charles Glass, In the Syria We Don't Know.

[06.112014] Jessica T. Mathews, Is There an Answer for Syria?

[05.02.2015] Sarah Birke, How ISIS Rules.

[07.05.2015] Annie Sparrow, Syria: Death from Assad's Chlorine.

[22.10.2015] Hugh Eakin, The Terrible Flight from the Killing.

[22.10.2015] Charles Glass, In the Syrian Deadlands.

[03.12.2015] Jonathan Steele, The Syrian Kurds Are Winning!

[17.12.2015] Michael Ignatieff, The Refugees \& the New War.

[10.03.2016] Hugh Eakin, Liberal, Harsh Denmark.

\footnotetext{
* Gwiazdką oznaczono teksty spoza analizowanego korpusu.
} 
[29.09.2016] Hugh Eakin, Ancient Syrian Sites: A Different Story of Destruction.

[13.10.2016] David Miliband, The Best Ways to Deal with the Refugee Crisis.

[10.11.2016] George Soros, On the Bombing of Aleppo.

[08.12.2016] Christian Caryl, The Kurds Are Nearly There.

[22.12.2016] Kenneth Roth, What Trump Should Do in Syria.

*[09.02.2017] Jessica T. Mathews, What Trump is Throwing out the Window.

[23.02.2017] Charles Glass, How Assad Is Winning.

[25.05.2017] Charles Glass, In the Horrorscape of Aleppo.

*[23.11.2017] Jessica T. Mathews, The Iran Deal: What's at Stake.

[23.11.2017] Lindsey Hilsum, War of All Against All.

[21.12.2017] Joost Hiltermann, A Likely Story.

[08.03.2018] Charles Glass, Syria's New Normal.

[19.04.2018] Lindsey Hilsum, The Smartphone War.

[24.05.2018] Steven Simon, Powder Keg in Syria.

[06.12.2018] Molly Crabapple, Where Else Can They Go?

[20.12.2018] Ed Vulliamy, 'It's What We Do.'

[07.02.2019] Charles Glass, Syria: A Savage Peace.

*[09.02.2019] Susie Linfield, Syria's Torture Photos: Witness to Atrocity, „NYR Daily” (https://

www.nybooks.com/daily/2019/02/09/syrias-torture-photos-witness-to-atrocity).

\section{ARE WE RESPONSIBLE FOR THE WORLD WE LIVE IN? THE WAR IN SYRIA AND THE DILEMMAS OF CONTEMPORARY WEST}

Waldemar Rapior

\section{Abstract}

This text concerns main moral issues connected with the armed conflict currently underway in Syria. On the basis of an analysis of texts published in the opinion-forming American journal The New York Review of Books, the author tries to show the complexity of the conflict in terms of the problems faced by world opinion. The author concludes that we, ordinary citizens, and the leaders of the world powers, in undertaking actions (participation in military actions, taking sides, humanitarian aid) had to resolve certain dilemmas and that in doing so they took into account their subjective interests. The author thus confirms his original thesis that the contemporary world is no longer guided by international solidarity or the UN principle of a "responsibility to protect."

\section{Key words / słowa kluczowe}

war in Syria / wojna w Syrii, world powers in the conflict in Syria / światowe mocarstwa w konflikcie syryjskim, international solidarity / międzynarodowa solidarność, evidence of crime / świadectwo zbrodni, refugees / uchodźcy, geopolitical dilemmas / dylematy geopolityki 